\title{
Perancangan Quadband BPF dengan Komponen Lumpeduntuk Sistem m-BWA
}

\section{Design of Quadband BPFUsing Lumped Components for m- BWA System}

\author{
Gunawan Wibisono*, Daniel Simanjuntak, dan Taufiq Alif Kurniawan \\ Departemen Teknik Elektro, Fakultas Teknik Universitas Indonesia \\ Kampus Baru UI, Depok 16424, Indonesia
}

\begin{abstract}
Abstrak
Ada banyak teknologi mobile broadband wireless access (m-BWA) yang saat ini digunakan, agar bisa mencakup seluruh teknologi m-BWA yang ada dalam sebuah perangkat maka diperlukan teknologi multiband. Salah satu komponen penting yang mendukung perkembangan teknologi m-BWA adalah bandpass filter (BPF), yang berfungsi untuk memilah-milah dan mengisolasi band yang spesifik dari interferensi pada transceiver radio frequency (RF). Pada penelitian ini akan dirancang quadband BPF yang beroperasi pada frekuensi tengah $950 \mathrm{MHz}$ dan 1,85 GHz untuk aplikasi GSM, 2,35 GHz untuk aplikasi WiMAX, dan 2,65 GHz untuk aplikasi LTE secara simultan. Rangkaian quadband BPF dibangun dan dikembangkan dari konsep dualband BPF dengan menambahkan sejumlah cross coupling pada inductive coupling BPF tersebut untuk menghasilkan zero pada frekuensi tertentu yang diharapkan menggunakan komponen lumped. BPF yang dirancang memiliki spesifikasi, input return loss $\left(\mathrm{S}_{11}\right)<-10 \mathrm{~dB}$, insertion loss $\left(\mathrm{S}_{21}\right)>-3 \mathrm{~dB}$, dan voltage standing wave ratio (VSWR) antara $1-2$, dan group delay kurang dari $10 \mathrm{~ns}$. Perancangan dilakukan menggunakan perangkat lunak Advance Design System (ADS) dan kemudian difabrikasi berbasis printed circuit board (PCB). Hasil simulasi BPF menunjukkan kinerja quadband BPF memenuhi kriteria perancangan sedangkan hasil fabrikasi mengalami pergeseran.
\end{abstract}

Kata kunci: quadband BPF, m-BWA, komponen lumped, insertion loss, return loss, VSWR, group delay.

\section{Abstract}

Nowadays, many technology of mobile broadband wireless access ( $m$-BWA)are using by users, in order to develop all $m$-BWA technologies into one device, multiband technology is proposed. One of important component which support m-BWA technology is bandpass filter $(B P F)$. BPF has function to enable band selecting in RF transceiver and isolate a specific band from interferers. In this research, a quadband BPF is design to operate at four specific center frequencies of $950 \mathrm{MHz}$ and $1.85 \mathrm{GHz}$ for GSM, 2.35 GHz for WiMAX, and $2.65 \mathrm{GHz}$ for LTE applications, simultaneously. The quadband BPF circuit is designed based on dualband $B P F$ by adding some cross coupling at inductive coupling BPF to produce zero at certain frequencies using lumped components. The design of filter must meet some requirements such as input return loss $\left(S_{11}\right)<-10 \mathrm{~dB}$, insertion loss $\left(S_{21}\right)>-3 \mathrm{~dB}$, and VSWR between $1-2$ with group delay < 10 ns. The design is simulated with Advanced Design System (ADS) software and fabricated using printed circuit based (PCB). The simulation results show that the performances of proposed quadband BPF are satisfied to the design requirements, while the measurement results are shifted from the requirements.

Keywords: quadband BPF, m-BWA, lumped component, insertion loss, return loss, VSWR, group delay.

\section{Pendahuluan}

Saat ini ada banyak teknologi mobile broadband wireless access (m-BWA) yang digunakan seperti Global System for Mobile Communications (GSM), Wide-band Code Division Multiple Access (WCDMA), Worldwide Interoperability for Microwave Access (WiMAX), dan Long Term Evolution (LTE). Kemajuan teknologi m-BWA menarik minat para peneliti untuk mengembangkan radio frequency $(\mathrm{RF})$ transceivers yang mampu bekerja pada beberapa pita frekuensi (multiband) secara bersamaan [1]-[6]. Teknologi GSM menggunakan frekuensi $900 \mathrm{MHz}$ dan 1,8 GHz, WCDMA pada

\footnotetext{
* Corresponding Author.

Email: gunawan@eng.ui.ac.id

Received: November 15, 2013; Revised: November 15, 2013

Accepted: Desember 23, 2013

Published: Desember 30, 2013

(C) 2013 PPET - LIPI

doi : 10.14203/jet.v13.47-54
}

frekuensi $1.9 \mathrm{GHz}$ dan 2,1 GHz, WiMAX pada frekuensi 2,3 GHz dan 3,3 GHz, serta LTE bekerja pada frekuensi 2,6 GHz. Semua teknologi m-BWA dimungkinkan dapat beroperasi pada satu perangkat untuk memberikan kemudahan bagi pengguna dan operator. Pada teknologi m-BWA, ukuran dan jumlah divais adalah pertimbangan penting dalam perancangan perangkat, saat ini divais SMD dengan ukuran yang lebih kecil dengan kehandalan tinggi banyak digunakan dalam perancangan perangkat m-BWA. Komponen lumped berupa induktor, kapasitor dan resistor dalam rangkaian microwave adalah komponen pasif dengan ukuran yang lebih kecil dari panjang gelombang operasi sehingga tidak ada pergeseran fasa yang besar antara terminal masukan dan keluaran [1].

Bandpass fiter (BPF) adalah komponen pada teknologi m-BWA yang berguna untuk memilih pita frekuensi pada RF transceiver dan mengisolasi pita frekuensi yang diinginkan dari sinyal yang diterima [7], [8]. Untuk memenuhi kebutuhan akan perangkat yang 
bekerja pada multi-frekuensi, teknik concurrent banyak digunakan dalam membangun sistem transceiver mBWA. Himanshu [1] dan Yong-Xin dkk. [2] menunjukkan penggunaan lumped komponen sebagai resonator untuk menghasilkan dualband BPF yang dapat bekerja dengan baik pada frekuensi 2,4 GHz dan $5,2 \mathrm{GHz}$ untuk aplikasi Wi-Fi. Yong-Xin dkk. [2] memperkenalkan dualband BPFsebagai penggabungan dua singleband BPF. Kedua singleband BPF tersebut didesain ulang sehingga salah satu BPF mempunyai karakteristik lowpass sedangkan yang lainnya highpass, sehingga satu filter akan open pada passband band filter lainnya. Ukuran filter ini relatif besar dan rangkaiannya yang sangat kompleks. Himanshu [1] juga memperkenalkan dualband BPF yang berbeda dengan Yong-Xin dkk. [2], di mana filter didesain dengan komponen lumped yang tersusun lebih padat untuk menghasilkan respon dualband dengan kedua frekuensi tengah setiap band dapat dikontrol secara mandiri.

Pada penelitian ini akan dirancang quadband $\mathrm{BPF}$ yang dikembangkan dari konsep dualband BPFyang diusulkan oleh Himanshu [1], dengan menambahkan sejumlah cross coupling pada inductive coupling BPF tersebut untuk menghasilkan zero pada frekuensi tertentu yang diharapkan [9], [10]. Rangkaian quadband BPF dirancang dengan menggunakan komponen lumped, dengan teknik concurrent multiband yang bekerja pada frekuensi tengah $950 \mathrm{MHz}, 1,85 \mathrm{GHz}, 2,35 \mathrm{GHz}$, dan $2,65 \mathrm{GHz}$. Filter ini memiliki nilai input return loss $\left(\mathrm{S}_{11}\right)$ $<-10 \mathrm{~dB}$, insertion loss $\left(\mathrm{S}_{21}\right)>-3 \mathrm{~dB}$, dan VSWR antara $1-2$ dengan group delay $<10 \mathrm{~ns}$.

Perancangan filter ini disimulasikan dengan menggunakan perangkat lunak Advanced Design System (ADS). Parameter-parameter filter yang akan dievaluasi meliputi frekuensi kerja, return loss, insertion loss, VSWR, bandwidth, dan group delay. Selain itu dilakukan juga pabrikasi dan hasilnya dibandingkan dengan hasil simulasi. Hasil akhir perancangan adalah rangkaian quadband $\mathrm{BPF}$ dengan menggunakan komponen lumped pada printed circuit board (PCB).

\section{Perancangan Quadband BPF}

Spesifikasi quadband BPF yang dirancang dapat dilihat pada Tabel 1 .

TABEL I

SPESIFIKASI QUADBAND BPF YANG DIRANCANG

\begin{tabular}{|l|c|c|c|c|}
\hline \multicolumn{1}{|c|}{ Parameter } & \multicolumn{4}{c|}{ Spesifikasi } \\
\hline Aplikasi & GSM & GSM & WiMAX & LTE \\
\hline Frekuensi tengah $(\mathrm{GHz})$ & 0,95 & 1,85 & 2,35 & 2,65 \\
\hline Bandwidth $(\mathrm{MHz})$ & 100 & 100 & 100 & 100 \\
\hline Return Loss $(\mathrm{dB})$ & $<-10$ & $<-10$ & $<-10$ & $<-10$ \\
\hline Insertion Loss $(\mathrm{dB})$ & $>-3$ & $>-3$ & $>-3$ & $>-3$ \\
\hline VSWR & $1-2$ & $1-2$ & $1-2$ & $1-2$ \\
\hline Group Delay $(\mathrm{ns})$ & $<10$ & $<10$ & $<10$ & $<10$ \\
\hline
\end{tabular}

Quadband BPF yang dirancang dalam penelitian merupakan pengembangan dualband BPF yang diusulkan Himanshu [1] menggunakan pendekatan inductive coupling BPF dengan menambahkan sejumlah cross coupling pada inductive coupling BPF untuk menghasilkan zero pada frekuensi tertentu. Konfigurasi dualband BPF [1] yang digunakan sebagai dasar perancangan quadband BPFditunjukkan pada Gambar 1.

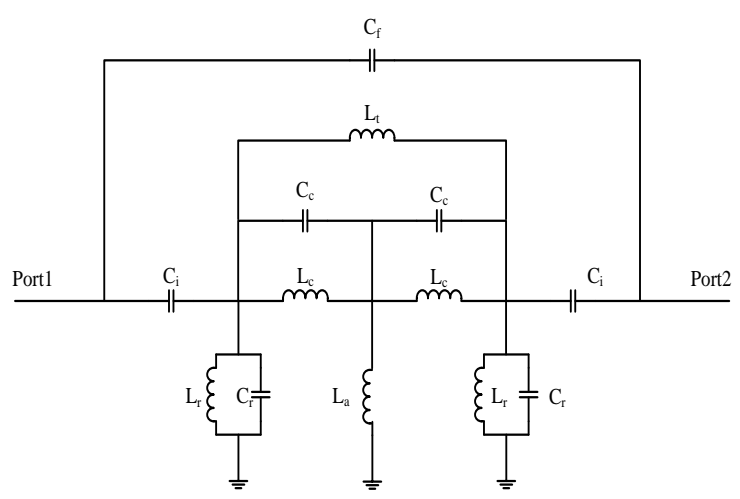

Gambar 1. Skematik Dualband BPF yang Diusulkan Himanshu [1].

Quadband BPFyang diusulkan dapat bekerja pada frekuensi tengah $950 \mathrm{MHz}, 1,85 \mathrm{GHz}, 2,35 \mathrm{GHz}$, dan 2,65 GHz. Seperti dijelaskan Himanshu [1], resonator paralel yang dibentuk oleh $\mathrm{L}_{\mathrm{r}}$ dan $\mathrm{C}_{\mathrm{r}}$ dengan kopling antar resonator $\mathrm{L}_{\mathrm{t}}$ akan menghasilkan frekuensi resonansi pada pita frekuensi yang lebih rendah sebagai passband pertama. Dengan nilai yang sesuai, inductor, $\mathrm{L}_{\mathrm{t}}$, dapat pula digunakan untuk menghasilkan passband pada frekuensi yang lebih tinggi, sebagai passband kedua. Konsep ini digunakan untuk merancang BPF yang bekerja pada frekuensi tengah $950 \mathrm{MHz}$ dan 2,35 GHz. Rangkaian quadband BPFyang bekerja pada frekuensi tengah 950 dan $2350 \mathrm{MHz}$ dapat dilihat pada Gambar 2.

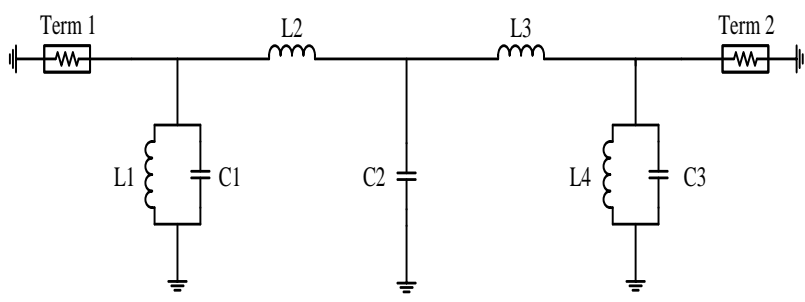

Gambar 2. Rangkaian quadband BPFpada frekuensi $950 \mathrm{MHz}$ dan 2,35 GHz.

Dengan menggunakan pendekatan seperti yang dilakukan Fabricio dkk. [11] dan asumsi bahwa $\mathrm{L}_{1}=\mathrm{L}_{4}$, $\mathrm{C}_{1}=\mathrm{C}_{3}$, dan $\mathrm{L}_{2}=\mathrm{L} 3$ maka nilai impedansi rangkaian pada Gambar 1., $\mathrm{Z}_{1}, \mathrm{Z}_{2}, \mathrm{Z}_{3}$, dan $\mathrm{Z}_{4}$ dapat dinyatakan sebagai

$$
\begin{aligned}
& Z_{1}=Z_{4}=\frac{\frac{s L_{1}}{s C_{1}}}{s L_{1}+\frac{1}{s C_{1}}}=\frac{s L_{1}}{s^{2} L_{1} C_{1}+1} \\
& Z_{2}=Z_{3}=Z_{1}+s L_{2}=\frac{s^{3} L_{1} L_{2} C_{1}+s\left(L_{1}+L_{2}\right)}{s^{2} L_{1} C_{1}+1}
\end{aligned}
$$

di mana $\mathrm{Z}_{1}$ adalah impedansi $\mathrm{L}_{1}$ dan $\mathrm{C}_{1}, \mathrm{Z}_{2}$ adalah impedansi $\mathrm{L}_{1}, \mathrm{~L}_{2}$, dan $\mathrm{C}_{1}, \mathrm{Z}_{3}$ adalah impedansi $\mathrm{L}_{3}, \mathrm{~L}_{4}$, dan $\mathrm{C}_{3}$, dan $\mathrm{Z}_{4}$ adalah impedansi $\mathrm{L}_{4}$ dan $\mathrm{C}_{3}$. Besarnya 
impedansi total, Z950MHz, 2350MHz dinyatakan oleh

$$
\begin{aligned}
Z_{950 \mathrm{M} z, 2350 \mathrm{Mz} z} & =\frac{1}{Z_{2}}+\frac{1}{Z_{3}}+\frac{1}{C 2}=\frac{C_{2} Z_{2}}{2 C_{2}+Z_{2}} \\
& =\frac{s\left(s^{2} L_{1} L_{2} C_{1}+L_{1}+L_{2}\right)}{s^{4} L_{1} L_{2} C_{1} C_{2}+s^{2}\left(L_{1} C_{2}+L_{2} C_{2}+2 L_{1} C_{1}\right)+2}
\end{aligned}
$$

Kondisi short terjadi apabila $\mathrm{Z}_{950 \mathrm{MHz}}, 2350 \mathrm{MHz}$ bernilai nol yaitu pada saat zero bernilai nol (pembilang pada pers (3) bernilai 0), sedangkan kondisi open terjadi apabila $\mathrm{Z}_{950 \mathrm{MHz}}, 2350 \mathrm{MHz}$ bernilai tak hingga yaitu ketika pole bernilai nol (penyebut pada Persamaan 3 bernilai 0). Rangkaian pada Gambar 1 memiliki sebuah zero yang akan beresonansi pada tiga frekuensi, yaitu $\omega_{\mathrm{a}}, \omega_{\mathrm{b}}$, dan $\omega_{\mathrm{c}}$. Untuk nilai $\omega_{\mathrm{b}}$ dimisalkan resonansi saat zero bernilai nol, sehingga Persamaan 3 dapat dinyatakan sebagai

$$
\begin{aligned}
& s\left(s^{2} L_{1} L_{2} C_{1}+L_{1}+L_{2}\right)=0 \\
& s^{2}=-\frac{L_{1}+L_{2}}{L_{1} L_{2} C_{1}}
\end{aligned}
$$

Bila $s=j \omega$, untuk kasus $\omega_{\mathrm{b}}$ maka Persamaan 4 dapat dinyatakan sebagai

$$
\omega_{b}^{2}=-\frac{L_{1}+L_{2}}{L_{1} L_{2} C_{1}}
$$

Sedangkan $\omega_{\mathrm{a}}$ dan $\omega_{\mathrm{c}}$ beresonansi pada saat pole bernilai nol terjadi, di mana dari Persamaan 3 didapat

$$
s^{4} L_{1} L_{2} C_{1} C_{2}+s^{2}\left(L_{1} C_{2}+L_{2} C_{2}+2 L_{1} C_{1}\right)+2=0
$$

Dengan menggunakan persamaan kuadrat, maka didapatkan

$$
\begin{aligned}
& \omega_{a}^{2}=\frac{\left(L_{1} C_{2}+L_{2} C_{2}+2 L_{1} C_{1}\right)-\sqrt{\left(L_{1} C_{2}+L_{2} C_{2}+2 L_{1} C_{1}\right)^{2}-8 L_{1} L_{2} C_{1} C_{2}}}{2 L_{1} L_{2} C_{1} C_{2}} \\
& \omega_{c}{ }^{2}=\frac{\left(L_{1} C_{2}+L_{2} C_{2}+2 L_{1} C_{1}\right)+\sqrt{\left(L_{1} C_{2}+L_{2} C_{2}+2 L_{1} C_{1}\right)^{2}-8 L_{1} L_{2} C_{1} C_{2}}}{2 L_{1} L_{2} C_{1} C_{2}}
\end{aligned}
$$

Dengan persyaratan bahwa $\omega_{\mathrm{a}}<\omega_{\mathrm{b}}<\omega_{\mathrm{c}}$, maka $\omega_{\mathrm{a}}$ diatur sedemikian sehingga beresonansi pada frekuensi $950 \mathrm{MHz}$ dan $\omega_{\mathrm{c}}$ beresonansi pada frekuensi $2,35 \mathrm{GHz}$ sedangkan $\omega_{\mathrm{b}}$ diatur beresonansi pada frekuensi di antara $950 \mathrm{MHz}$ dan 2,35 GHz. Hasil simulasi return loss $\mathrm{S}_{11}$ yang menyatakan frekuensi resonansi untuk $\omega_{\mathrm{a}}$ dan $\omega_{\mathrm{c}}$ dapat ditunjukkan pada Gambar 3.

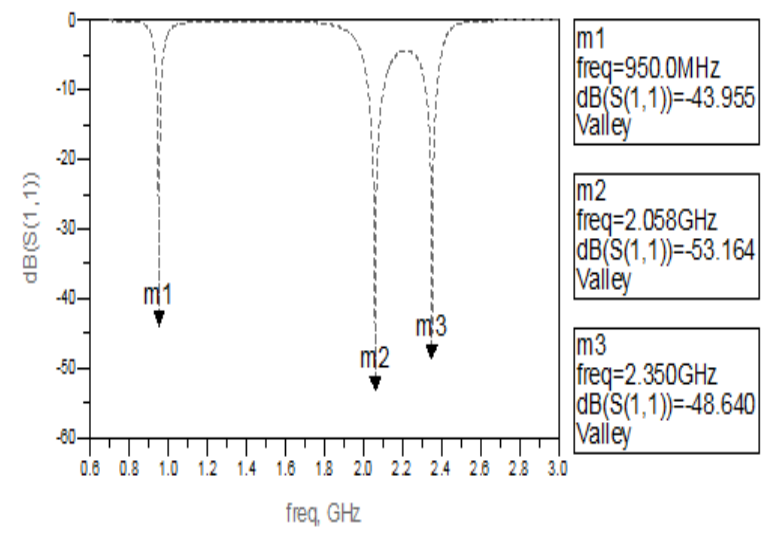

Gambar 3. Hasil Simulasi $S_{11}$ pada Frekuensi $950 \mathrm{MHz}$ dan 2,35 GHz.
Hasil simulasi $S_{11}$ dapat diperoleh dengan nilai komponen BPF yang digunakan, diberikan pada Tabel 2.

TABEL II

KOMPONEN BPF UNTUK FREKUENSI 950 MHZ DAN 2,35 GHz

\begin{tabular}{|c|c|c|c|}
\hline Komponen & Nilai (nH) & Komponen & Nilai $(\mathbf{p F})$ \\
\hline $\mathrm{L}_{1}$ & 0,76 & $\mathrm{C}_{1}$ & 15,6 \\
\hline $\mathrm{L}_{2}$ & 0,80 & $\mathrm{C}_{2}$ & 26,7 \\
\hline $\mathrm{L}_{3}$ & 0,80 & $\mathrm{C}_{3}$ & 15,6 \\
\hline $\mathrm{L}_{4}$ & 0,76 & & \\
\hline
\end{tabular}

Dari Gambar 3 terlihat bahwa frekuensi resonansi $\omega_{\mathrm{b}}$ (m2 pada Gambar 3) dari nilai zero tidak mudah diatur untuk beresonansi pada frekuensi tertentu tanpa mempengaruhi frekuensi resonansi $\omega_{\mathrm{a}}(\mathrm{m} 1$ pada Gambar 3) dan $\omega_{\mathrm{c}}$ (m3 pada Gambar 3). Tetapi bila diinginkan menggeser frekuensi resonansi $\omega_{\mathrm{a}}$ dan $\omega_{\mathrm{c}}$ tanpa mengganggu frekuensi resonansi $\omega_{\mathrm{b}}$, dapat dilakukan dengan mengubah nilai $\mathrm{C}_{2}$. Jika $\omega_{\mathrm{b}}$ diinginkan sebagai passband kedua yang bekerja pada frekuensi $1,85 \mathrm{GHz}$ tanpa mempengaruhi $\omega_{\mathrm{a}}$ dan $\omega_{\mathrm{c}}$, maka untuk mencapainya, konfigurasi rangkaian BPF yang digunakan terlihat pada Gambar 4.

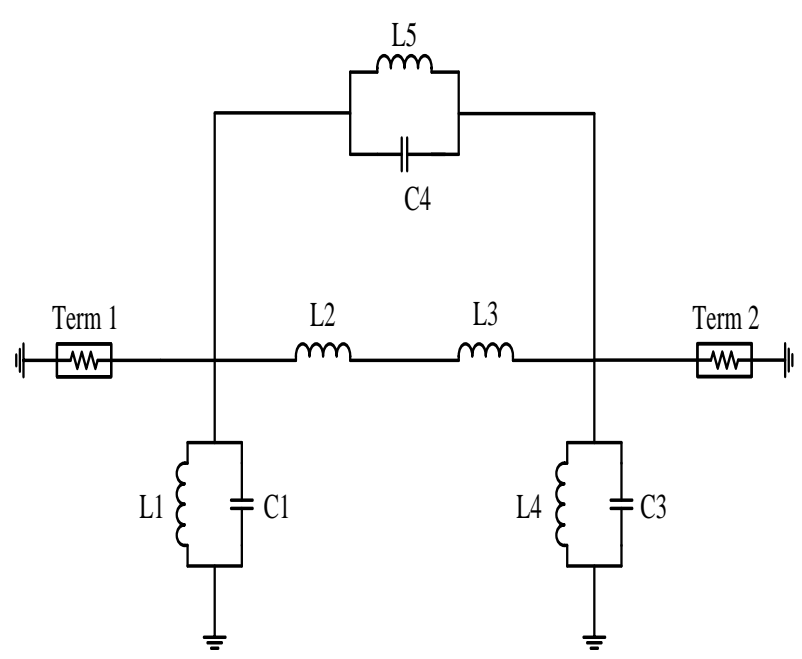

Gambar 4. Rangkaian Quadband BPF pada Frekuensi 1,85 GHz.

Jika diasumsikan $\mathrm{L} 1=\mathrm{L} 4, \mathrm{C} 1=\mathrm{C} 3$, dan $\mathrm{L} 2=\mathrm{L} 3$ maka nilai impedansi total untuk beresonansi pada frekuensi 1,850 $\mathrm{GHz}$ pada dari rangkaian pada Gambar 3 dapat dinyatakan sebagai

$$
Z_{1,85 G H_{z}}=\frac{s^{2}\left(s^{2}\left(4 L_{1} C_{1} L_{2} L_{5}+2 L_{1} L_{2} L_{5} C_{4}\right)+4 L_{2} L_{5}+L_{1} L_{5}+2 L_{1} L_{2}\right)}{s^{5} 4 C_{1} C_{4} L_{1} L_{2} L_{5}+2 s^{3}\left(L_{2} L_{5} C_{4}+L_{1} C_{1}\left(L_{5}+2 L_{2}\right)\right)+S\left(L_{5}+2 L_{2}\right)}
$$

Bila diharapkan resonansi pada frekuensi $1,85 \mathrm{GHz}$ terjadi, maka dari Persamaan 8 didapat

$$
\omega_{1,85 G H z}^{2}=\frac{4 L_{2} L_{5}+L_{1} L_{5}+2 L_{1} L_{2}}{4 L_{1} C_{1} L_{2} L_{5}+2 L_{1} L_{2} L_{5} C_{4}}
$$

Untuk membuat resonansi pada $1,85 \mathrm{GHz}$, maka dilakukan penggeseran frekuensi resonansi yang dihasilkan dari zero tersebut, dilakukan dengan penambahan induktor dan kapasitor sebagai cross coupling terhadap kopling utama. Di mana induktor digunakan untuk mengubah nilai zero. Penambahan cross coupling ini tidak memindahkan frekuensi resonansi yang dihasilkan dari pole karena cross 
coupling ini hanya berfungsi untuk mengunci zero pada sumbu $\mathrm{j} \omega$ (real frequency). Apabila induktor $\mathrm{L}_{5}$ dan $\mathrm{C}_{4}$ pada Gambar 4 diubah-ubah nilainya maka frekuensi resonansi yang dihasilkan dari zero akan bergeser sedangkan frekuensi resonansi lainnya tidak berubah. Demikian juga sebaliknya, apabila komponen yang sudah ada sebelum penambahan cross coupling ini diubah-ubah nilainya maka frekuensi resonansi dari zero tidak akan berubah karena cross coupling sudah mengunci frekuensi resonansi tersebut pada posisinya. BPF yang bekerja pada frekuensi tengah $950 \mathrm{MHz}, 1,85$ $\mathrm{GHz}$ dan 2,35 $\mathrm{GHz}$ dihasilkan dengan pemilihan nilai komponen $\mathrm{L}_{5}$ dan $\mathrm{C}_{4}$ yang sesuai, dengan sedikit penyesuaian pada nilai komponen yang terdapat pada Tabel 2 maka diperoleh nilai komponen seperti pada Tabel 3. Hasil simulasi $S_{11}$ diperlihatkan oleh Gambar 5. untuk frekuensi $1,85 \mathrm{GHz}$.

TABEL III

KOMPONEN BPF UNTUK FREKUENSI 1,85 GHZ

\begin{tabular}{|c|c|c|c|}
\hline Komponen & Nilai $(\mathbf{n H})$ & Komponen & Nilai (pF) \\
\hline $\mathrm{L}_{1}$ & 0,75 & $\mathrm{C}_{1}$ & 15,5 \\
\hline $\mathrm{L}_{2}$ & 0,75 & $\mathrm{C}_{3}$ & 15,5 \\
\hline $\mathrm{L}_{3}$ & 0,85 & $\mathrm{C}_{4}$ & 3,71 \\
\hline $\mathrm{L}_{4}$ & 0,82 & & \\
\hline $\mathrm{L}_{5}$ & 3,14 & & \\
\hline
\end{tabular}

Passband ketiga dihasilkan dengan penambahan kapasitor di antara resonator paralel yang dibentuk oleh $\mathrm{L}_{\mathrm{r}}$ dan $\mathrm{C}_{\mathrm{r}}$ pada Gambar 4. Untuk mengontrol pergerakan zero yang dihasilkan pada quadband BPF dapat dilakukan dengan menambahkan cross copling lainnya menggunakan induktor maupun kapasitor di antara dua resonator tersebut [9], [10].

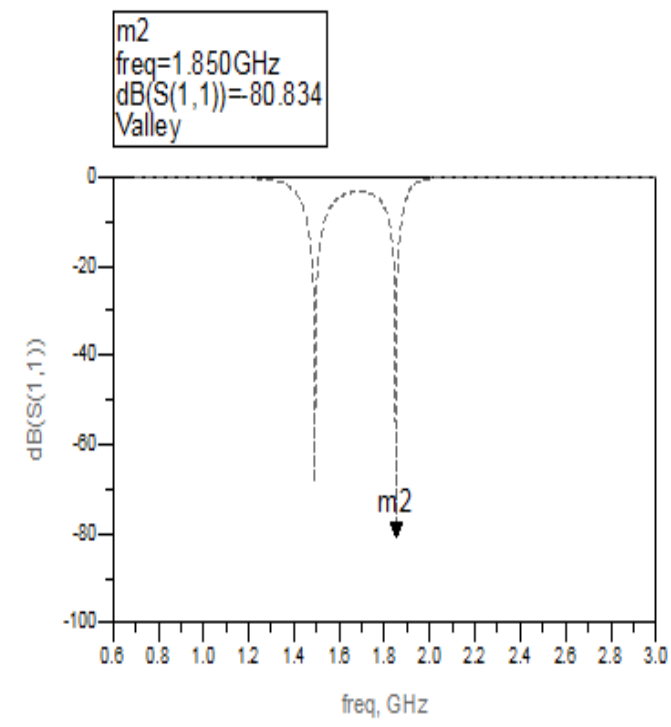

Gambar 5. Hasil Simulasi $S_{11}$ pada Frekuensi 1,85 GHz.

Untuk realisasi passband keempat, dilakukan dengan memindahkan zero dari tak hingga ke frekuensi 2,65 $\mathrm{GHz}$ dengan menggunakan induktor $\mathrm{L}_{6}$ yang dipasang secara seri terhadap cross coupling yang terdapat pada Gambar 4.Pada kondisi ini, induktor $\mathrm{L}_{6}$ juga berfungsi sebagai cross coupling bersama-sama dengan induktor $\mathrm{L}_{5}$ dan kapasitor $\mathrm{C}_{4}$. Konfigurasi rangkaian untuk memperoleh passband kedua pada 1,85
$\mathrm{GHz}$ dan passband keempat pada 2,65 $\mathrm{GHz}$ diperlihatkan pada Gambar 6.

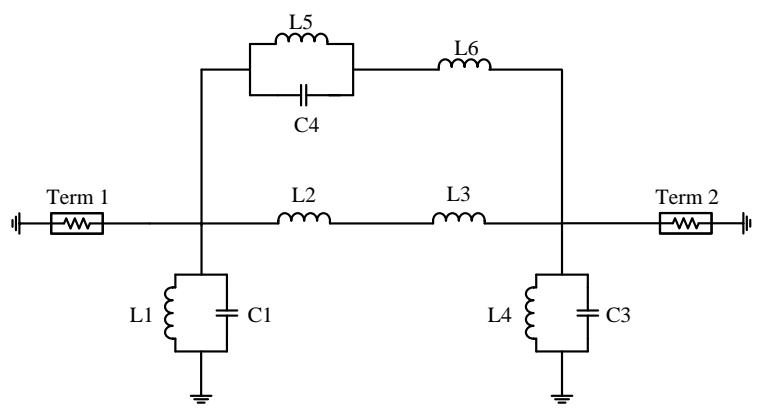

Gambar 6. Rangkaian Quadband BPF pada Frekuensi $1,85 \mathrm{GHz}$ dan $2,65 \mathrm{GHz}$.

Untuk menggeser frekuensi resonansi kedua menjadi $1,85 \mathrm{GHz}$ dapat dilakukan dengan mengubahubah nilai $\mathrm{L}_{5}$ dan $\mathrm{C}_{4}$ sedangkan untuk menggeser frekuensi resonansi keempat menjadi 2,65 $\mathrm{GHz}$ dapat dilakukan dengan mengubah-ubah nilai $\mathrm{L}_{6}$ tanpa menggeser frekuensi resonansi kedua secara signifikan. Hal ini bisa dicapai dengan mengatur $\mathrm{L}_{5}, \mathrm{~L}_{6}$, dan $\mathrm{C}_{4}$ mempunyai sifat impedansi yang berbeda pada kedua frekuensi tersebut. Untuk penelitian ini, $\mathrm{L}_{5}, \mathrm{~L}_{6}$, dan $\mathrm{C}_{4}$ diatur agar lebih bersifat kapasitif pada frekuensi 1,85 $\mathrm{GHz}$ dan lebih bersifat induktif pada frekuensi 2,65 GHz. Dengan pemilihan komponen yang sesuai seperti yang terdapat pada Tabel 4, dapat dihasilkan BPF yang bekerja pada frekuensi $1,85 \mathrm{GHz}$ dan $2,65 \mathrm{GHz}$.

TABEL IV

KOMPONEN BPF PADA FREKUENSI 1,85 GHz DAN 2,65 GHz

\begin{tabular}{|c|c|c|c|}
\hline Komponen & Nilai (nH) & Komponen & Nilai (pF) \\
\hline L1 & 0,75 & C1 & 15,50 \\
\hline L2 & 0,85 & C3 & 15,50 \\
\hline L3 & 0,82 & C4 & 3,725 \\
\hline L4 & 0,75 & & \\
\hline L5 & 2,64 & & \\
\hline L6 & 2,64 & & \\
\hline
\end{tabular}

Hasil simulasi $S_{11}$ pada frekuensi $1,85 \mathrm{GHz}$ dan 2,65 diperlihatkan oleh Gambar 7.

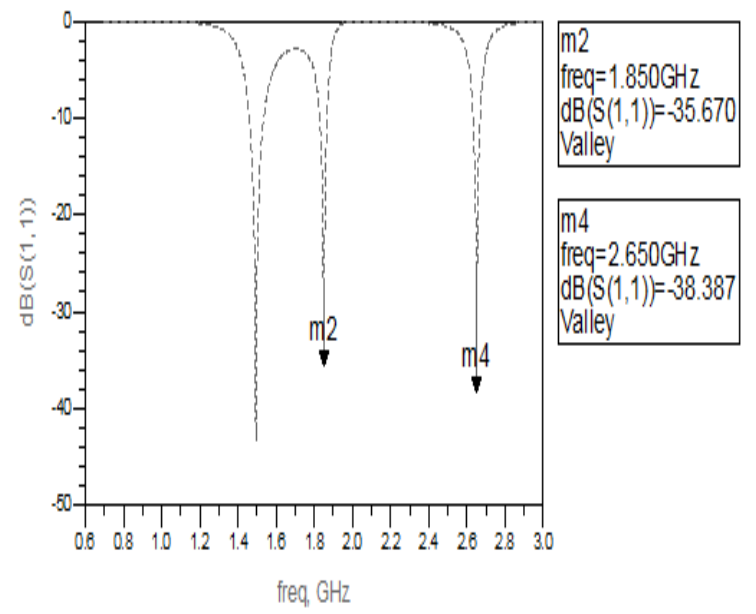

Gambar 7. Hasil Simulasi $S_{11}$ pada Frekuensi 1,85 GHz dan 2,65 GHz.

Untuk realisasi quadband BPF dapat dilakukan dengan memasukkan nilai-nilai komponen yang terdapat 
pada Tabel 3 dan Tabel 4.pada rangkaian quadband $\mathrm{BPF}$ yang terdapat pada Gambar 6., kapasitor $\mathrm{C}_{5}$ dan $\mathrm{C}_{6}$ berfungsi sebagai kopling antara port masukan dan port keluaran dengan quadband BPF dan sekaligus sebagai DC block dengan nilai $10 \mathrm{pF}$. Kapasitor ini tidak memberikan pengaruh yang signifikan terhadap frekuensi resonansi filter. Tabel 5 memperlihatkan nilai komponen untuk quadband BPF dari Gambar 6.

TABEL V

KOMPONEN BPF UNTUK KEEMPAT PASSBAND

\begin{tabular}{|c|c|c|c|}
\hline Komponen & Nilai (nH) & Komponen & Nilai (pF) \\
\hline L1 & 0,75 & C1 & 15,5 \\
\hline L2 & 0,85 & C2 & 26,0 \\
\hline L3 & 0,82 & C3 & 15,5 \\
\hline L4 & 0,75 & C4 & 3,7 \\
\hline L5 & 2,74 & C5 & 10,0 \\
\hline L6 & 2,57 & C6 & 10,0 \\
\hline
\end{tabular}

Hasil simulasi $\mathrm{S}_{11}$ untuk keempat passband diperlihatkan oleh Gambar 8.

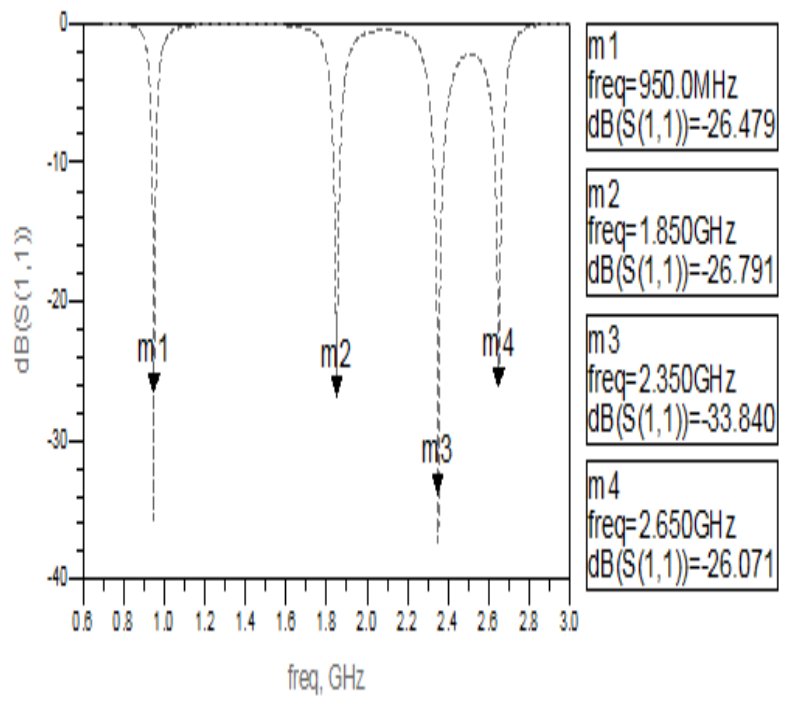

Gambar 8.Hasil Simulasi $\mathrm{S}_{11}$ untuk Keempat Passband.

\section{HASIL DAN ANALISA}

\section{A. Simulasi}

1) Return Loss

Hasil simulasi output return loss $\left(\mathrm{S}_{22}\right)$ rangkaian quadband BPFdiperlihatkan pada Gambar 9. Hasil simulasi menunjukkan bahwa rangkaian quadband BPF mampu beroperasi pada empat frekuensi yang berbeda. Nilai output return loss yang kecil mengakibatkan transmissi power ke quadband BPF dari sumber berjalan lebih optimal. Pada Gambar 9 dapat dilihat bahwa $S_{22}$ memiliki nilai yang yang mendekati nilai terendah pada frekuensi tengahnya, yaitu pada $950 \mathrm{MHz}, 1,85 \mathrm{GHz}$, 2,35 GHz, dan 2,65 GHz. Dari hasil simulasi, dapat disimpulkan bahwa quadband BPF dapat bekerja pada keempat frekuensi yang diinginkan.

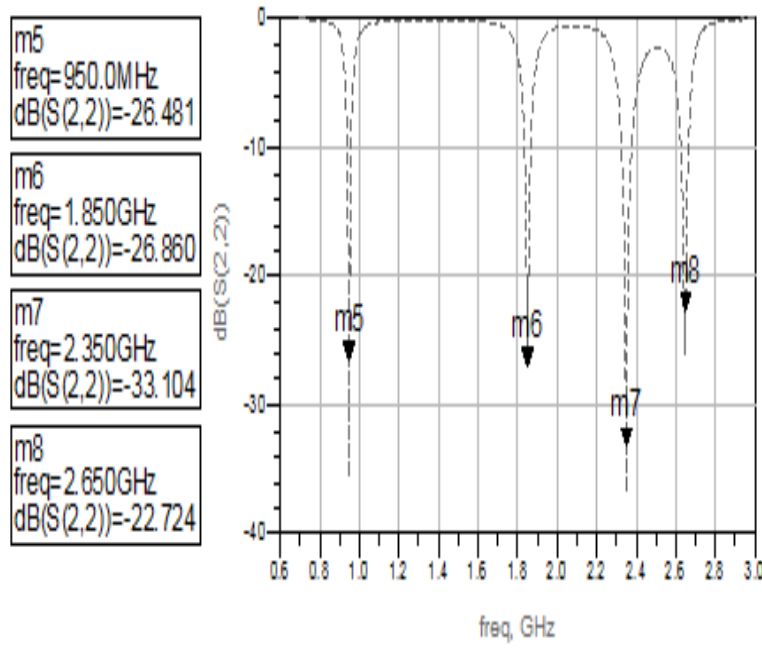

Gambar 9. Hasil Simulasi Output Return Loss $\left(\mathrm{S}_{22}\right)$.

\section{2) Insertion Loss $\left(\mathrm{S}_{21}\right)$}

Hasil simulasi insertion loss $\left(\mathrm{S}_{21}\right)$ rangkaian quadband BPF diperlihatkan pada Gambar 10. Hasil simulasi menunjukkan bahwa rangkaian quadband $\mathrm{BPF}$ mampu beroperasi pada empat frekuensi yang berbeda. Nilai insertion loss yang mendekati nol menunjukkan semakin kecil daya yang hilang akibat penyisipan filter di antara kedua port. Pada Gambar 10. dapat dilihat bahwa S21 memiliki nilai yang yang mendekati nol pada frekuensi tengahnya, yaitu pada $950 \mathrm{MHz}, 1,85 \mathrm{GHz}$, 2,35 GHz, dan 2,65 GHz. Dari hasil simulasi tersebut, dapat disimpulkan bahwa quadband BPF dapat bekerja pada keempat frekuensi yang diinginkan.

\begin{tabular}{l}
\hline $\begin{array}{l}\mathrm{LL} 1 \\
\text { freg }=950.0 \mathrm{MHz} \\
\mathrm{dB}(\mathrm{S}(2,1))=-0.010\end{array}$ \\
$\begin{array}{l}\mathrm{LL} 2 \\
\text { freg }=1.850 \mathrm{GHz} \\
\mathrm{dB}(\mathrm{S}(2,1))=-0.009\end{array}$ \\
$\begin{array}{l}\mathrm{L3} 3 \\
\text { freg }=2.350 \mathrm{GHz} \\
\mathrm{dB}(\mathrm{S}(2,1))=-0.002\end{array}$ \\
$\begin{array}{l}\mathrm{LL} 4 \\
\mathrm{freq}=2.650 \mathrm{GHz} \\
\mathrm{dB}(\mathrm{S}(2,1))=-0.023\end{array}$ \\
\hline
\end{tabular}

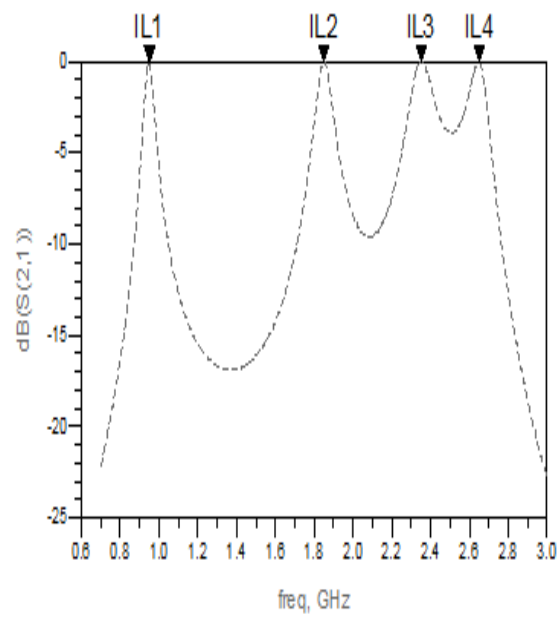

Gambar 10. Hasil Simulasi Insertion Loss $\left(\mathrm{S}_{21}\right)$.

Untuk quadband BPF ini, dengan menggunakan nilai insertion loss pada Gambar 3. lebih besar dari -3 $\mathrm{dB}$, bandwidth yang diperoleh adalah sebesar $56 \mathrm{MHz}$ dan $96 \mathrm{MHz}$ masing-masing pada 950 dan $1800 \mathrm{MHz}$, $162 \mathrm{MHz}$ pada 2,35 GHz, dan $127 \mathrm{MHz}$ pada 2,65 GHz.

3) VSWR

Nilai VSWR masing-masing frekuensi telah mencapai kondisi yang diharapkan, yaitu memiliki nilai antara 1 - 2 pada semua frekuensi kerja quadband BPF tersebut. Dari Gambar 11. tampak bahwa hasil simulasi VSWR mendekati nilai 1 pada frekuensi tengah 950 $\mathrm{MHz}, 1,85 \mathrm{GHz}, 2,35 \mathrm{GHz}$, dan 2,65 GHz. 


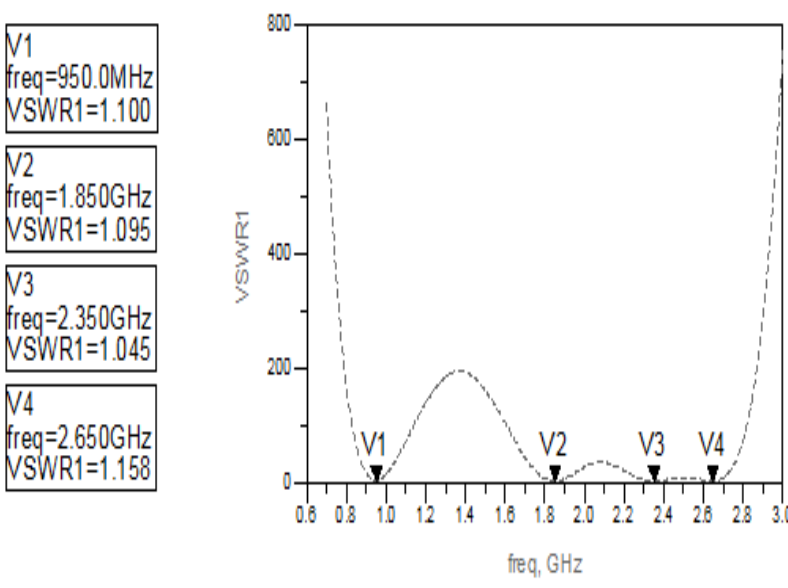

Gambar 11. Hasil Simulasi VSWR.

\section{4) Group Delay}

Gambar 12. menunjukkan group delay yang terjadi pada keempat passband yang diinginkan, yaitu 950 $\mathrm{MHz}, 1,85 \mathrm{GHz}, 2,35 \mathrm{GHz}$, dan 2,65 GHz. Pada 950 $\mathrm{MHz}$ terjadi group delay sebesar 5,627 ns, pada 1,85 $\mathrm{GHz}$ terjadi group delay sebesar $3,445 \mathrm{~ns}$, pada 2,35 $\mathrm{GHz}$ terjadi group delay sebesar 2,420 ns, dan pada 2,65 $\mathrm{GHz}$ terjadi group delay sebesar 3,088 ns. Hal ini menunjukkan bahwa group delay yang terjadi kurang dari 10 ns. Group delay yang dihasilkan tidak akan menyebabkan perubahan fasa yang signifikan sehingga tidak menyebabkan terjadinya distorsi pada sinyal yang dilewatkan.


Gambar 12. Hasil Simulasi Group Delay.

\section{B. Pabrikasi}

Hasil pabrikasi quadband BPF yang dirancangd apat dilihat pada Gambar 13.

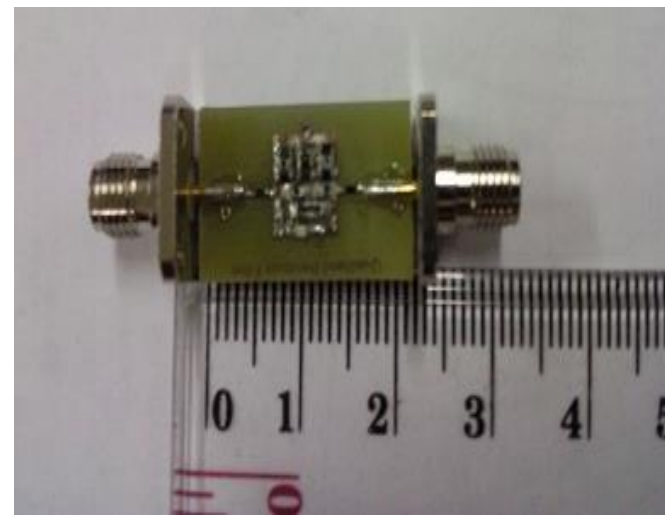

Gambar 13.Quadband BPF Hasil Pabrikasi.

\section{1) Input Return Loss $\left(S_{11}\right)$}

Hasil simulasi input return loss $\mathrm{S}_{11}$ rangkaian quadband BPF tampak pada Gambar 14. Hasil pengukuran menunjukkan bahwa rangkaian quadband BPF hasil pabrikasi sebenarnya mampu beroperasi pada empat frekuensi yang berbeda, tetapi tidak beroperasi pada frekuensi kerja yang diinginkan.

\section{2) Insertion Loss $\left(S_{21}\right)$}

Hasil pengukuran insertion loss $\left(\mathrm{S}_{21}\right)$ rangkaian quadband BPF tampak pada Gambar 15. Hasil menunjukkan bahwa rangkaian quadband BPF hasil pabrikasi tidak beroperasi pada empat frekuensi yang diharapkan. Di mana nilai insertion loss yang diharapkan berada di atas $-3 \mathrm{~dB}$ tidak tercapai seperti yang diperlihatkan Gambar 15.

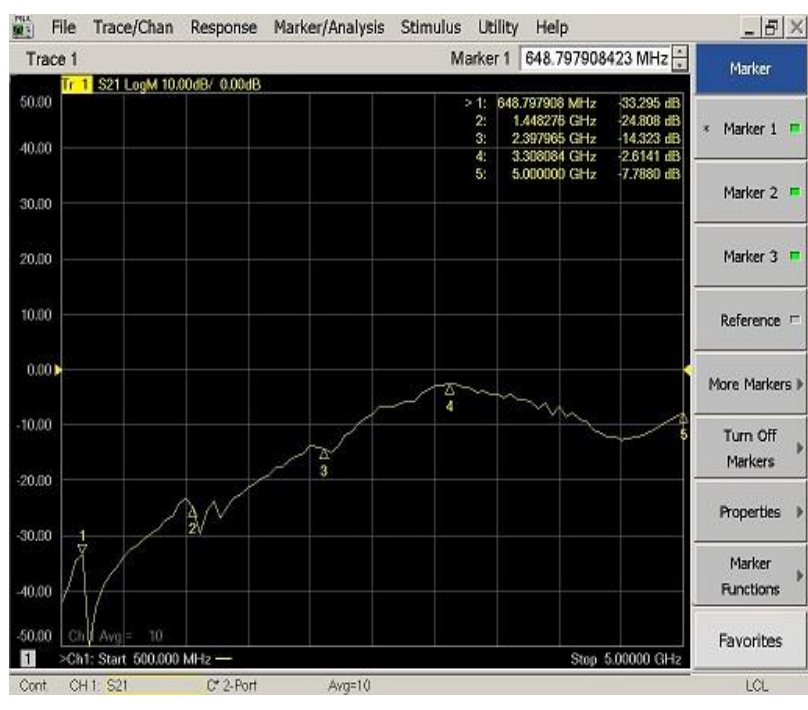

Gambar 15. Insertion Loss Hasil Fabrikasi

\section{3) VSWR}

Dari Gambar 16 tampak bahwa hasil simulasi VSWR pada frekuensi yang diharapkan tidak tercapai. Nilai VSWR yang seharusnya berada di bawah 2 pada frekuensi kerja $950 \mathrm{MHz}, 1,85 \mathrm{GHz}, 2,35 \mathrm{GHz}$, dan 2,65 $\mathrm{GHz}$ belum terpenuhi.

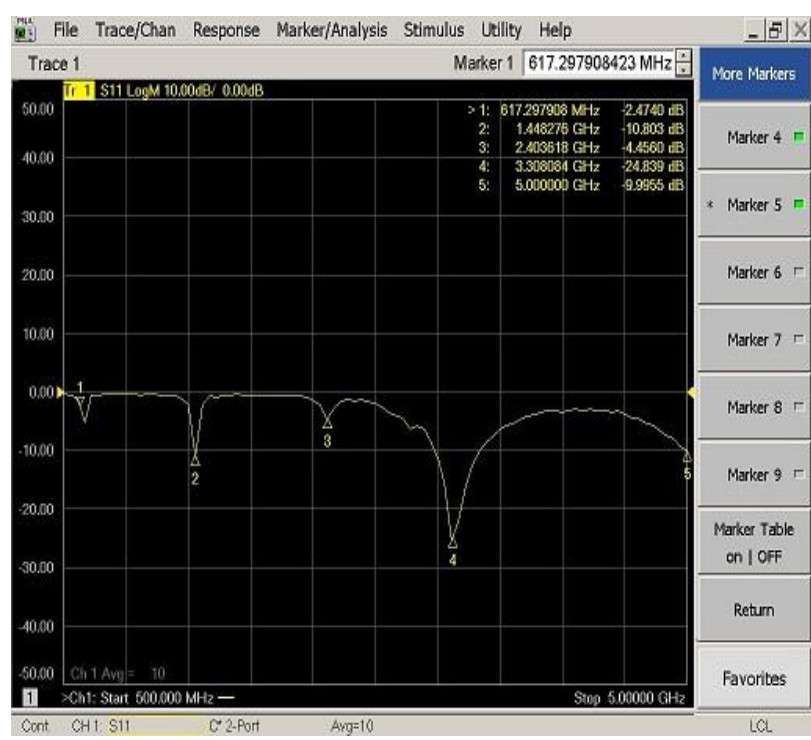

Gambar 14. Input Return Loss Hasil Pabrikasi. 


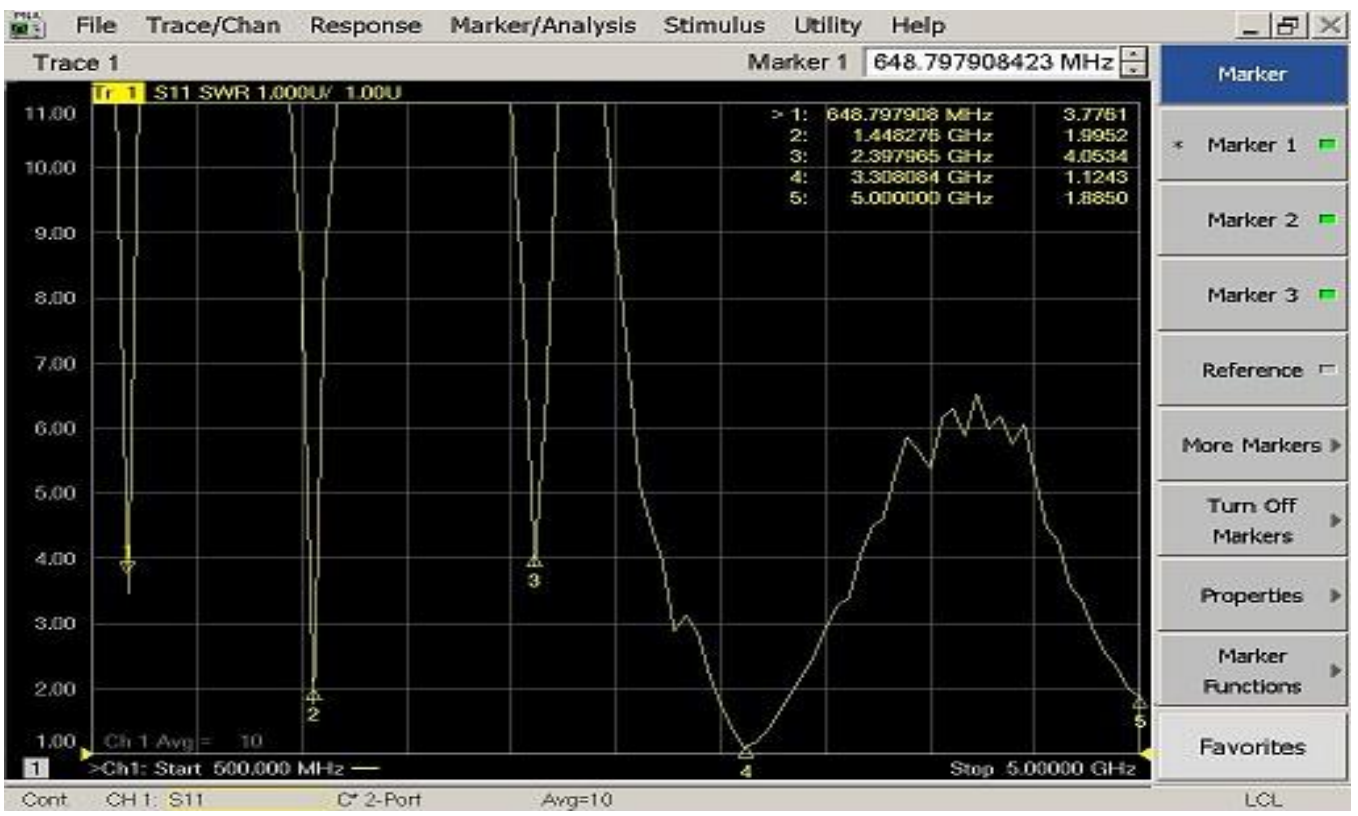

Gambar 16. VSWR Hasil Pabrikasi

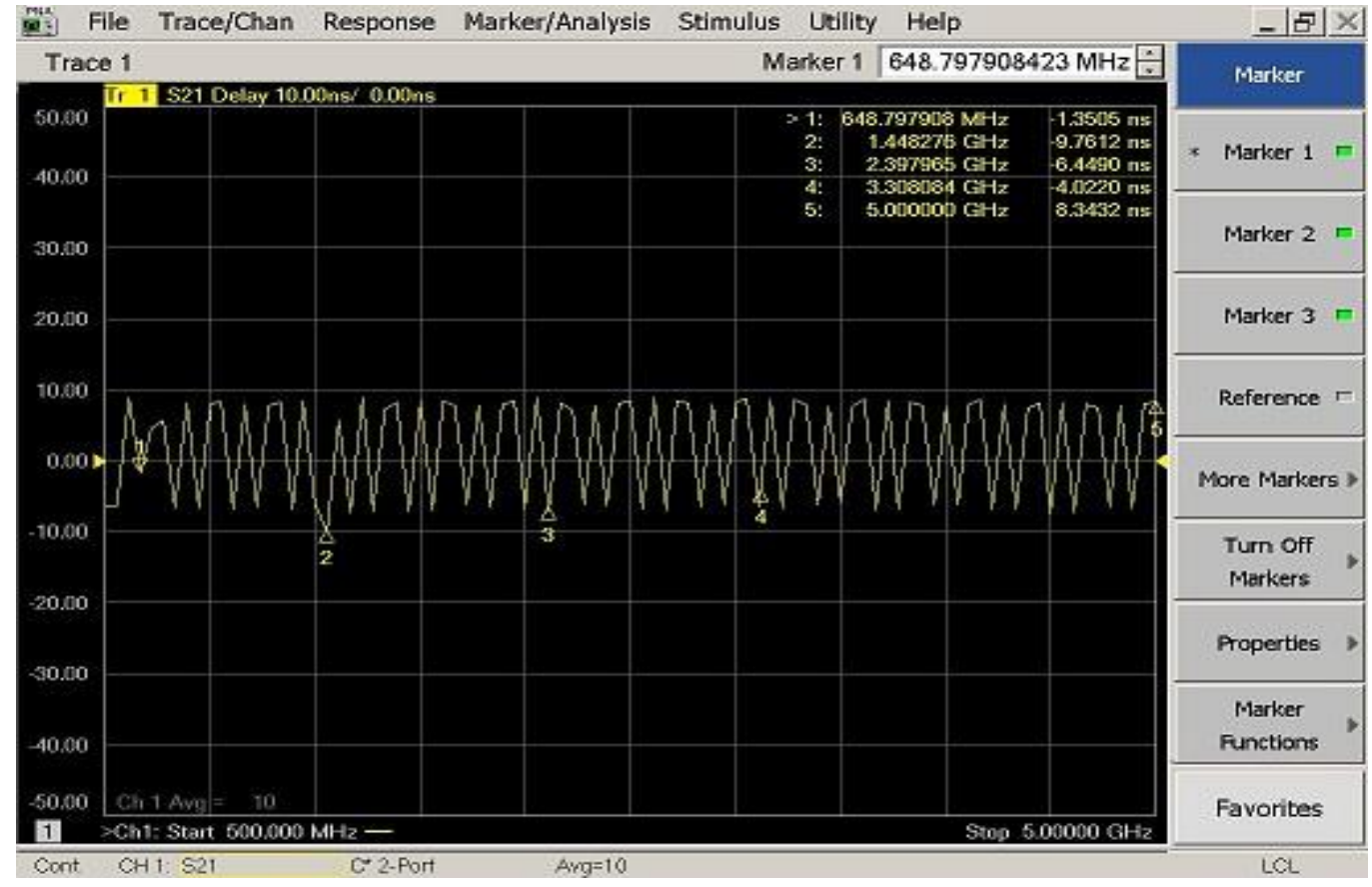

Gambar 17. Group Delay Hasil Pabrikasi.

\section{4) Group Delay}

Gambar 17 menunjukkan group delay yang terjadi pada quadband BPF hasil pabrikasi. Seperti yang terlihat pada gambar tersebut group delay yang terjadi di bawah 10 ns sehingga tidak akan terjadi distorsi pada sinyal yang dilewatkan.

Hasil fabrikasi belum sesuai dengan kriteria perancangan dikarenakan antara lain adalah nilai komponen yang digunakan tidak sesuai dengan hasil perhitungan, fabrikasi PCB yang kurang presisi, dan proses penyolderan yang kurang baik.

\section{KESIMPULAN}

Quadband BPF yang dikembangkan dari konsep dualband BPF dengan menambahkan sejumlah cross coupling pada inductive coupling BPF untuk menghasilkan zero pada frekuensi tertentu yang diharapkan telah berhasil dirancang dan dipabrikasi. Kinerja quadband BPF yang dinyatakan dengan insertion loss, return loss, VSWR, dan group delay disimulasikan, diukur, dan dibandingkan. Rangkaian quadband BPF dirancang menggunakan komponen lumped dengan teknik concurrent multiband yang bekerja pada frekuensi tengah $950 \mathrm{MHz}, 1,85 \mathrm{GHz}, 2,35$ $\mathrm{GHz}$, dan 2,65 GHz. Quadband BPF yang dirancang memiliki bandwidth sebesar $56 \mathrm{MHz}$ dan $96 \mathrm{MHz}$ masing-masing pada frekuensi $950 \mathrm{MHz}$ dan $1,80 \mathrm{GHz}$, $162 \mathrm{MHz}$ pada frekuensi $2,35 \mathrm{GHz}$, dan $127 \mathrm{MHz}$ untuk frekuensi 2,65 $\mathrm{GHz}$ pada insertion loss $>-3 \mathrm{~dB}$. Quadband BPF ini memiliki nilai return loss $\mathrm{S}_{11}<-10$ 
$\mathrm{dB}$, insertion loss $\mathrm{S}_{21}>-3 \mathrm{~dB}$, dan VSWR antara $1-2$ dengan group delay kurang dari 10 ns untuk keempat frekuensi. Kinerja quadband BPF hasil pabrikasi menunjukkan belum sesuai dengan hasil simulasi dikarenakan oleh antara lain toleransi komponen yang tinggi, fabrikasi yang kurang presisi, dan proses penyolderan yang kurang baik.

\section{UCAPAN TERIMA KASIH}

Penelitian ini didanai oleh Hibah Riset Strategi Nasional Dikti Tahun 2013 dengan nomor kontrak No. 2502/H2.R12/HKAP.05.00/2013.

\section{DAFTAR PUSTAKa}

[1] H. Joshi, "Multiband RF Bandpass Filter Design", Dissertation, Purdue University, Indiana, Mei, 2010

[2] Y. X. Guo, L.C. Ong, M. Y. W. Chia, dan B. Luo, "Dual-band bandpass filter in LTCC", Microwave Symposium Digest, 2005 IEEE MTT-S International, 2005, pp. 2219 - 2222.

[3] M. Steer, Microwave and RF Design : A Systems Approach, North Carolina, USA: SciTech Publishing, Inc., 2010.
[4] A. B. Fathoni, "Rancang Bangun Multiband dengan Folded Dual Cross Open Stub", Thesis, Universitas Indonesia, Depok, Indonesia, 2012.

[5] H. Xie, L. He, P. Shen, J. Gan, L. Li, Y. Huang, L. Huang, and W. Zhang, "A novel dual-band power amplifier for wireless communication", IEEE 2009 International Conference on Communication Software and Networks, 2009, pp. 332 - 335.

[6] C. W Sayre, Complete Wireless Design, 2nd ed., New York, USA: The McGraw-Hill Companies Inc., 2008.

[7] I. Bahl, Lumped Elements for RF and Microwave Circuits, Boston, USA: Artech House, 2003.

[8] D. M. Pozar, Microwave Engineering Third Edition, New Jersey, USA: John Wiley \& Son, Inc., 2005

[9] R. J. Wenzel, "Understanding transmission zero movement in cross-coupled filters". Microwave Symposium Digest, 2003 IEEE MTT-S International, 2003, pp. 1459 - 1462.

[10] C. W. Tang, Y. C. Lin, and C. Y. Chen, "Realization of transmission zeros in combine filters using an auxiliary inductively coupled ground plane", IEEE Transactions on Microwave Theory and Techniques, vol. 51, pp. 2112 - 2118, October 2003.

[11] F. G. S. Silva, R. N. de Lima, and R. C. S. Freire, "A design methodology for concurrent impedance matching networks based on multiresonant circuits", New Circuits and Systems Conference (NEWCAS), 2011 IEEE 9th International, Jun 2229,2011 , pp. $386-389$ 